\title{
ARTYKUtY
}

Klio. Czasopismo poświęcone dziejom Polski i powszechnym

PL ISSN 1643-8191, t. 47 (4)/2018, s. 9-27

(c) (1) $\Theta$

http://dx.doi.org/10.12775/KLIO.2018.047

TOMASZ ŁADOŃ

\section{Rozwój kariery politycznej Lucjusza Korneliusza Sulli w latach dziewięćdziesiątych I wieku przed Chrystusem}

\section{The Development of Political Career of Lucius Cornelius Sulla in the Nineties of the First Century B.C.}

Streszczenie: Celem autora artykułu było określenie politycznej roli, jaką Lucjusz Korneliusz Sulla odgrywał w Republice Rzymskiej w latach dziewięćdziesiątych I wieku przed Chrystusem. Autor skupił się przede wszystkim na karierze urzędniczej Sulli. Omówił kwestie chronologiczne z nią związane, przedstawił powody rezygnacji Sulli ze startu w wyborach na edyla, szczegółowo zaprezentował także genezę walki Sulli o uzyskanie pretury miejskiej, sprawowanie przez Sullę tego urzędu oraz początek kampanii o konsulat zahamowanej przez wybuch wojny ze sprzymierzeńcami.

Według autora artykułu ważnym wydarzeniem dla rozwoju dalszej kariery politycznej Sulli było zerwanie sojuszu z Gajuszem Mariuszem i stopniowe zbliżanie się do factio Metellusów, zakończone zawarciem formalnego sojuszu, przypieczętowanego małżeństwem Sulli z Cecylią Metellą.

* Uniwersytet Humanistyczno-Przyrodniczy im. Jana Długosza w Częstochowie, tladon@wp.pl, ORCID: 0000-0003-0481-0484. 
Abstract: The author's goal was to determine the political role played by Lucius Cornelius Sulla in the Roman Republic in the nineties of the First Century BC. The author focused on the Sulla's political career. He discussed the chronological issues associated with it, presented the reasons for Sulla's resignation from the start to the edilship, he also presented in detail the genesis of Sulla's struggle for praetura, Sulla's exercise of this office and the beginning of the campaign for the consulate stopped by the outbreak of the Social War. According to the author of the article, an important event for the development of Sulla's further political career was the breaking of the alliance with Gaius Marius and gradual approach to the Metellan factio ended with the conclusion of a formal alliance, sealed by Sulla and Cecilia Metella marriage.

Słowa kluczowe: Lucjusz Korneliusz Sulla, pretura, Gajusz Mariusz, kariera polityczna.

Keywords: Lucius Cornelius Sulla, praetura, Gaius Marius, political career.

U

progu I wieku ${ }^{1}$ Lucjusz Korneliusz Sulla był już postacią dobrze znaną rzymskiej elicie politycznej. Zawdzięczał to jednakże sukcesom odniesionym podczas kampanii wojennych. Najpierw w 107 roku pełnił w Afryce kwesturę u boku Gajusza Mariusza i w trakcie działań przeciwko królowi numidyjskiemu Jugurcie przyczynił się do jego pojmania, co przyspieszyło zakończenie konfliktu, Sulli zaś przysporzyło sławy ${ }^{2}$. Kolejne laury wojenne zbierał podczas inwazji Germanów na Italię, służąc najpierw w randze legata i trybuna wojskowego pod wodzą Gajusza Mariusza, by w dalszym toku wojny przejść pod komendę konsula 102 roku, Kwintusa Lutacjusza Katulusa ${ }^{3}$. Dokonania Sulli i zdobyta dzięki nim popularność Chrystusa.

${ }^{1}$ Wszystkie daty w tekście artykułu odnoszą się do czasów przed narodzeniem

${ }^{2}$ Działania Sulli w trakcie wojny Rzymu z Jugurtą najpełniej opisuje Salustiusz (Iug. 95-113). Informacje o pozostałych relacjach źródłowych zebrał T.R.S. Broughton (The Magistrates of the Roman Republic, vol. 1, New York 1950, s. 551, 554, 556). Szerzej o udziale Sulli w wojnie jugurtyńskiej T. Dijkstra, V. Parker, Through Many Glasses Darkly: Sulla and the End of Jugurthine War, „Wiener Studien” 2007, 120, s. 142-160.

${ }^{3}$ Plut., Sull. 4.1-4, Praec. ger. rei pub. 12. Por. P.F. Cagniart, L. Cornelius Sulla's Quarrel with C. Marius at the Time of the Germanic Invasions (104-101 B.C.), „Athenaeum” 1989, 67, s. 139-147. 
wśród ludu rzymskiego dawały mu nadzieję na osiągnięcie kolejnych szczebli w rzymskiej karierze urzędniczej.

Celem niniejszego artykułu jest próba rekonstrukcji przebiegu kariery Sulli od momentu jego powrotu do Rzymu po zakończeniu wojny z Germanami aż do wybuchu wojny ze sprzymierzeńcami w 90 roku. Skupię się przy tym jedynie na aspektach związanych z polityczną działalnością Sulli w Rzymie, czyli na jego staraniach o uzyskanie kolejnych urzędów państwowych czy próbach szukania przez niego sojuszników wśród wpływowych przedstawicieli arystokracji senatorskiej. Postaram się także wyjaśnić wątpliwości dotyczące chronologii kariery przyszłego dyktatora w pierwszym dziesięcioleciu I wieku. Mniej uwagi poświęcę natomiast zagranicznej aktywności Sulli, czyli namiestnictwu na Wschodzie, które sprawował po zakończeniu pretury w Rzymie.

Interesujące mnie zagadnienie dość słabo zostało opisane przez autorów antycznych, zwłaszcza jeśli porównać je z innymi fragmentami życiorysu przyszłego dyktatora. Plutarch z Cheronei w „Żywocie Sulli” poświęcił jego działalności w latach dziewięćdziesiątych zaledwie jeden rozdział (gdy cała biografia Sulli liczy ich aż 38), w dodatku skażony propagandą sullańską ${ }^{4}$. Drobne wzmianki na temat wczesnej kariery politycznej Sulli można znaleźć w innych przekazach źródłowych - np. u Wellejusza Paterkulusa, w periochach dzieła Liwiusza czy u Waleriusza Maksymusa, i dotyczą one przede wszystkim pełnionej przez Sullę pretury ${ }^{5}$, namiestnictwa w Cylicji ${ }^{6}$ oraz zatargu z Marcjuszem Censorinusem, do którego doszło po powrocie Sulli z Azji do Rzymu? .

Wątła baza źródłowa nie przeszkodziła współczesnym badaczom w próbach rekonstrukcji kariery Sulli w latach dziewięćdziesiątych. Ogromne zainteresowanie tą problematyką wynika w dużej mierze z roli, jaką Lu-

${ }^{4}$ Plut., Sull. 5. Z tekstu wynika, że Plutarch oparł ów rozdział na Pamiętnikach Sulli. Zob. M.G. Angeli Bertinelli, Silla [w:] Plutarco, Le Vite di Lisandro, e di Silla, Milano 1997, s. 309-315.

${ }^{5}$ Liv., Per. 70; Vell. 2.17.3; Val. Max. 7.5.5. Zob. także: Cic., Font. 43; Plin., NH 8.53; Vir. Ill. 75.3; Sen., Brev. Vit. 13.6.

${ }^{6}$ Liv., Per. 70; Plut., Sull. 5.3-6; App., Mith. 57; Vir. Ill. 75.4. Por. Vell. Pat. 2.24.3; Front., Str. 1.5.18.

7 Plut., Sull. 5.6; Firm. Mat. 1.7.28. 
cjusz Korneliusz Sulla odegrał w późniejszym okresie Republiki. Początkom kariery politycznej Sulli poświęcono kilka wnikliwych artykułów. Badacze starali się patrzeć na to zagadnienie z różnych perspektyw, najczęściej próbowali rozwiązać nieścisłości chronologiczne związane z przebiegiem politycznej drogi przyszłego dyktatora, odtwarzali jego starania o preturę, badali sprawowanie przez niego tego urzędu, obszerniej zajmowali się także jego namiestnictwem w Azji po złożeniu pretury ${ }^{8}$. Także w licznych biografiach Sulli rekonstrukcja jego wczesnej kariery politycznej zajmuje ważne miejsce'. W literaturze wyodrębniają się przy tym - jak można zauważyć dwie wyraźne tendencje: z jednej strony patrzy się na karierę Sulli w latach dziewięćdziesiątych przez pryzmat jego późniejszych osiągnięć, a co za tym idzie - przecenia się jego ówczesne wpływy polityczne w państwie ${ }^{10}$, z drugiej zbyt mocno deprecjonuje się rolę Sulli i postrzega jako kogoś pozostającego poza pierwszym planem ówczesnej polityki, kogoś, kto co najwyżej doprowadził podupadłą w ostatnich latach gałąz rodu do poziomu przodków, czyli osiągnął preturę i traktował ją jako szczyt swoich możliwości ${ }^{11}$. Takie biegunowe podejście nie wydaje się słuszne. Oczywiście trzeba mieć

${ }^{8}$ E. Badian, Sulla's Cilician Command, [w:] idem, Studies in Greek and Roman History, Oxford 1964, s. 157-178; A. Sherwin-White, Ariobarzanes, Mithridates, and Sulla, „The Classical Quarterly” 1977, 27, s. 173-183; G.V. Sumner, Sulla's Career in the Nineties, „Athenaeum” 1978, 66, s. 395-396; A. Keaveney, Deux dates contestées de la carriere de Sylla, „Les Études Classiques” 1980, 48, s. 149-157; P.F. Cagniart, L. Cornelius Sulla in the Nineties: a Reassessment, „Latomus” 1991, 50, s. 285-303; T. Corey Brennan, Sulla's Career in the Nineties: Some Reconsiderations, "Chiron” 1922, 22, s. 103-158; F.X. Ryan, The Second Praetorian Campaign of Sulla (Plut. Sull. 5, 1-4), „Maia” 1995, 47, s. 399-403; C.R. Hatscher, Sullas Karriere in den Neunziger Jahren: Ansätze der Forschung (1830-1992), „Hermes“ 2001, 129, s. 208-224.

${ }^{9}$ F. Hinard, Sylla, Fayard 1985, s. 47-53; L.E. Reams, The First Fifty Years of Sulla: A Reassessment, University of California diss. 1985, s. 88-114; W. Letzner, Lucius Cornelius Sulla. Versuch einer Biographie, Münster 2000, s. 81-104; K. Christ, Sulla. Eine römische Karriere, München 2002, s. 72-74; G. Brizzi, Silla, Roma 2004, s. 71-75; J. Fündling, Sulla, Darmstadt 2010, s. 45-50; Ł. Schreiber, Sulla 138-78 p.n.e., Zabrze 2013, s. 97-107; L. Telford, Sulla. A Dictator Reconsidered, Barnsley 2014, s. 71-80; A. Keaveney, Sulla. Ostatni republikanin, przeł. T. Ładoń, Oświęcim 2017, s. 40-47.

${ }^{10}$ G.P. Baker, Sulla the Fortunate. Roman General and Dictator, New York 2001 (reprint wyd. London 1927), s. 152-157; A. Keaveney, Sulla..., s. 49 i n.

${ }^{11}$ Tak np. P.F. Cagniart, L. Cornelius Sulla..., s. 298-299. 
na uwadze stosunkowo niską pozycję Sulli w gronie rządzącej ówcześnie arystokracji, ale należy w nim jednak widzieć przedstawiciela starego patrycjuszowskiego rodu ${ }^{12}$, któremu z pewnością nie brakowało ambicji i który - jak każdy Rzymianin o jego zdolnościach i pochodzeniu - dążył do osiągnięcia jak najwyższej pozycji w Republice.

Karierę polityczną sensu stricto L. Korneliusz Sulla rozpoczął po powrocie do Rzymu z wojny z Germanami. Zwykle kolejnym po kwesturze urzędem piastowanym przez Rzymian, chcących w przyszłości starać się o konsulat, był edylat. Według Plutarcha Sulla postanowił jednak ominąć ten urząd i od razu wystartować w wyborach pretorskich. Zrobił to wbrew oczekiwaniom ludu rzymskiego, który - co zresztą biograf z Cheronei powtarza za "Pamiętnikami” przyszłego dyktatora ${ }^{13}$ - chciał, aby najpierw piastował on edylat, w nadziei, że dzięki znajomości z królem Mauretanii Bokchusem, zawartej w czasie wojny jugurtyńskiej, zorganizuje w Rzymie wspaniałe igrzyska uświetnione walkami dzikich zwierząt. W konsekwencji - po rezygnacji Sulli ze starań o edylat - niezadowolony lud nie zagłosował na niego w wyborach pretorskich i jego kandydatura przepadła ${ }^{14}$.

Opisane wydarzenie budzi u współczesnych badaczy szereg wątpliwości. Pierwsza jest natury chronologicznej, zastanawiano się mianowicie, kiedy Sulla wystartował po raz pierwszy w wyborach pretorskich. Aby odpowiedzieć na to pytanie, należy najpierw ustalić datę pretury Sulli, Plutarch podaje bowiem, że pełnił ją w następnym roku po wspomnianej klęsce wyborczej ${ }^{15}$. Bezpośrednią wskazówkę chronologiczną dotyczącą pretury Sulli odnaleźć można w dziele Wellejusza Paterkulusa. Historyk ów twierdzi, że przyszły dyktator sprawował preturę rok przed wybuchem wojny ze sprzymierzeńcami ${ }^{16}$. Jako że w innym miejscu swego przekazu Wellejusz

12 Sulla wywodził się z Cornelii Rufini et Sullae (jednej z gałęzi gens Cornelia), której założycielem był dyktator 334 roku P. Korneliusz Rufinus. Przodkowie Sulli nie dochodzili co prawda do konsulatów, ale osiągali preturę i piastowali najwyższe urzędy kapłańskie. Stanowili zatem ówczesną elitę, choć nie pierwszy jej szereg. O znaczeniu rodu Sulli w Republice zob. L.E. Reams, The First Fifty Years of Sulla..., s. 11-33.

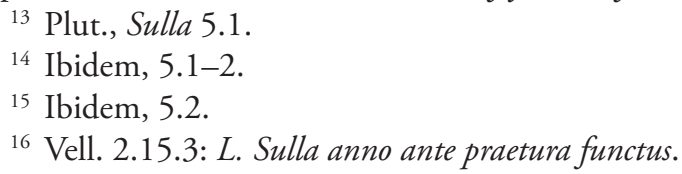


Paterkulus wskazuje, że bellum sociale rozpoczęła się za konsulatu Lucjusza Juliusza Cezara i Publiusza Rutyliusza ${ }^{17}$, czyli w roku 90, to wynika z tego, że preturę Sulli datuje na rok 91. Problem polega jednak na tym, że taka datacja jest niewątpliwie błędna - wiadomo wszakże, że Sulla po złożeniu pretury wyjechał z Italii, aby pełnić namiestnictwo prowincji, nie mógł zatem sprawować pretury w 91 roku, skoro w 90 roku brał udział w wojnie ze sprzymierzeńcami. Skłoniło to badaczy do przesunięcia terminu pełnienia pretury przez Sullę wstecz na 93 rok $^{18}$.

Tę tradycyjną, obowiązującą w dawnej historiografii datę zakwestionował dopiero Ernst Badian. Zrekonstruował on chronologię życia Sulli i ustalił, że przyszły dyktator urodził się niemal na pewno w 138 roku, w 107 roku pełnił kwesturę u boku Mariusza, po czym do 101 roku nieprzerwanie uwikłany był w służbę wojskową. Następnie, po powrocie do Rzymu, ominął start w wyborach na edyla i nieudanie wystartował w wyborach na pretora w 99 roku (na rok 98). Wybory udało mu się wygrać dopiero w roku następnym (czyli 98), preturę zatem sprawował w roku $97^{19}$. Następnie - w randze prokonsula - udał się do Cylicji, by w latach 96-95 sprawować w niej namiestnictwo. Do Rzymu powrócił pod koniec $95 \mathrm{roku}^{20}$. Zaproponowana przez Badiana chronologia, w tym datacja pretury Sulli, została zaakceptowana przez większość badaczy ${ }^{21}$.

17 Vell. 2.15.1. E. Badian, Sulla's Cilician Command..., s. 158.

18 A.H.J. Greenidge, A.M. Clay, Sources for Roman History B.C. 133-70, Oxford 1903, s. 95; D. Magie, Roman Rule in Asia Minor to the End of the Third Century Aftter Christ, vol. 1, Princeton 1950, s. 206; T.R.S. Broughton, The Magistrates..., vol. 2, New York 1952, s. 14-15.

19 E. Badian, Sulla's Cilician Command..., s. 158-160.

${ }^{20}$ Ibidem, s. 160-162, 172-173.

${ }^{21}$ A. Keaveney, Deux dates..., s. 157; P.F. Cagniart, L. Cornelius Sulla..., s. 291; W. Letzner, Lucius Cornelius Sulla..., s. 93; G. Brizzi, Silla..., s. 71; J. Fündling, Sulla..., s. 44; L. Telford, Sulla..., s. 71; Ł. Schreiber, Sulla..., s. 96. Część historyków uważa, że od powrotu Sulli ze Wschodu do wybuchu wojny ze sprzymierzeńcami, w której Sulla służył jako legat konsula L. Juliusza Cezara, istnieje zbyt duża przerwa w życiorysie przyszłego dyktatora i przesuwają okres pretury Sulli na 95 rok. Zob. G.V. Sumner, Sulla's Career..., s. 395-396; F.X. Ryan, The Second Praetorian Campaign of Sulla..., s. 399, przyp. 1. Problem w moim przekonaniu rozwiązał T. Corey Brennan (Sulla's Career..., s. 154-158; idem, The Praetorship of the Roman Republic, Oxford 2000, s. 358, który przyjmuje za 
Druga wątpliwość związana z relacją Plutarcha o starcie Sulli w wyborach pretorskich wiąże się z powodami zaniechania przez przyszłego dyktatora starań o edylat. Taka decyzja Sulli może dziwić, tym bardziej że najwidoczniej zdawał on sobie sprawę z tego, że lud rzymski oczekuje od niego startu w wyborach na ów urząd. Współcześni badacze postępowanie Sulli najczęściej tłumaczą pośpiechem i potrzebą nadrobienia straconego na wojnach czasu. Otóż Sulla, zajęty przez ostatnie osiem lat służbą wojskową, osiągnął w międzyczasie odpowiedni wiek do ubiegania się o preturę. Gdyby wystartował w wyborach na edyla na rok 98 lub (raczej) $97^{22}$, musiałby odczekać dwa lata (tzw. biennium), aby móc objąć kolejny urząd kurulny. Jeśliby więc wygrał wybory na edyla na rok 97, najwcześniej mógłby wystartować w wyborach pretorskich w 95 roku na rok 94. Sulla najwidoczniej nie chciał czekać tak długo. Taka zwłoka wstrzymałaby wszak jego karierę na kilka lat. W dodatku przez ten czas wyblakłaby pamięć o jego niedawnych sukcesach wojennych odniesionych w wojnie z Jugurtą i Germana$\mathrm{mi}^{23}$. Jeśli dodać do tego cechującą przyszłego dyktatora arystokratyczną pewność siebie, to jego decyzja o starcie od razu w wyborach pretorskich z pominięciem edylatu - wydaje się w pełni zrozumiała.

Nieco inaczej kwestię zaniechania przez Sullę startu w wyborach na edyla przedstawia Pierre Cagniart. Zdaniem tego uczonego Sullę powstrzymały względy praktyczne, których wymienia kilka: koszty zarówno kampanii wyborczej, jak i sprawowania edylatu, wiążące się z urządzaniem różnego rodzaju rozrywek dla ludu za własne pieniądze, większe szanse w wyborach na preturę, gdzie wybierano sześciu kandydatów, a nie dwóch,

Badianem, że Sulla pełnił preturę w 97 roku, ale na podstawie wnikliwej analizy źródeł przedłuża jego namiestnictwo w Cylicji do 93 lub nawet 92 roku. Por. T.R.S. Broughton, The Magistrates..., vol. 3, Atlanta 1986, s. 73-74; C.R. Hatscher, Sullas Karriere..., s. 211-222.

${ }^{22}$ W okresie Republiki obowiązywała zasada, że edylat naprzemiennie pełnili patrycjusze i plebejusze. Jeśli ta zasada obowiązywała w pierwszej dekadzie I wieku, a nie jest to pewne (zob. T.R.S. Broughton, The Magistrates..., vol. 1, s. 490, przyp. 4-5), 97 rok był rokiem patrycjuszy i Sulla prawdopodobnie nie mógł wystartować w wyborach na edyla w 99 roku. Zob. E. Badian, Sulla's Cilician Command..., s. 174, przyp. 16; P.F. Cagniart, L. Cornelius Sulla..., s. 288, przyp. 11.

${ }^{23}$ A. Keaveney, Sulla..., s. 40. 
jak w przypadku edylatu, brak poparcia Mariusza, z którym Sulla wszedł w konflikt w okresie wojny z Germanami, oraz prawdopodobnie ówcześnie małe ambicje Sulli. Według Cagniarta ominięcie przez Sullę nieobligatoryjnego w cursus honorum edylatu - uważanego za ważny krok na drodze do konsulatu - świadczy bowiem o tym, że Sulla u progu lat dziewięćdziesiątych nie planował w przyszłości ubiegać się o najwyższy urząd w państwie i postrzegał preturę jako szczyt swoich możliwości politycznych ${ }^{24}$.

Przedstawione przez Cagniarta argumenty wydają się jednak mało przekonujące. Możliwości finansowe Sulli były znacznie większe, niż można sądzić na podstawie przekazu Plutarcha ${ }^{25}$, a dodatkowo dzięki bogactwu zgromadzonemu na wojnach z Jugurtą i Germanami sytuacja majątkowa Sulli niewątpliwie się poprawiła. Wypada także zauważyć, że Sulla w trakcie pretury wystawił igrzyska, co jasno dowodzi, że było go stać na realizację takiego przedsięwzięcia. Rzekomy konflikt Sulli z Mariuszem, do którego miało dojść pod koniec II wieku, jest hipotezą forsowaną przez Cagniarta w osobnym artykule ${ }^{26}$, jest ona jednak trudna do zaakceptowania ${ }^{27}$. Podejmowane przez tego badacza dywagacje na temat większych szans Sulli w wyborach na preturę niż na edylat, w sytuacji, gdy nie znamy żadnego nazwiska edyla z roku 98, czy też hipotetyczne rozważania na temat ówczesnych ambicji Sulli pozbawione jakiegokolwiek potwierdzenia w materiale źródłowym wydają się zaś co najmniej ryzykowne.

Nie wszyscy badacze wierzą we wspomnianą wyżej wersję wypadków opisaną przez Plutarcha (zaczerpniętą wszakże przez niego od Sulli) o zaniechaniu przez Sullę startu w wyborach na edylat i nie podzielają opartych na niej ustaleń badaczy. Sumner na przykład uważa ${ }^{28}$, że przyjęcie rekonstrukcji i chronologii Badiana (pretura Sulli 97, namiestnictwo Cylicji 96-95)

24 P.F. Cagniart, L. Cornelius Sulla..., s. 289-290.

25 Zob. L.E. Reams. Zob. idem, Sulla's Alleged Early Poverty and Roman Rent, „American Journal of Ancient History” 1984, 9, s. 158-174. Por. jednak T.W. Hillard, Sulla's Early Fortune and his Reputation, „Antichthon” 1991, 25, s. 63-71, który uważa, że Sulla na skutek rozpustnego stylu życia został w młodości wydziedziczony przez ojca.

26 P.F. Cagniart, L. Cornelius Sulla's Quarrel..., s. 139-147.

${ }^{27}$ Co jasno wykazał L.E. Reams, Censorinus..., s. 286. Por. idem, The First Fifty Years of Sulla..., s. 106-110.

${ }^{28}$ G.V. Sumner, Sulla's Career..., s. 396. 
powoduje, że w następnych pięciu latach w życiorysie Sulli dochodzi do zadziwiającego braku aktywności, gdyż dopiero w 90 roku zostaje on legatem L. Juliusza Cezara w wojnie ze sprzymierzeńcami ${ }^{29}$. Według Sumnera taki stan rzeczy jest nieprawdopodobny, wobec czego zaproponował on hipotezę, że po przegranych pierwszych wyborach pretorskich Sulla - wbrew zapisowi Plutarcha - zapewne nie zignorował woli ludu i jeszcze w tym samym 99 roku zgłosił swą kandydaturę na edyla kurulnego i wybory te wygrał. Następnie przyszły dyktator w trakcie edylatu (sprawowanego w 98 roku) zorganizował obiecane ludowi okazałe igrzyska, po złożeniu urzędu odczekał wymagane prawem dwa lata (biennium) i w 96 roku, tym razem z sukcesem, wystartował w wyborach na urząd pretora, który pełnił w 95 roku. Zgodnie z tą hipotezą w 94 roku Sulla sprawowałby namiestnictwo Cylicji i pierwszą szansę na start w wyborach konsularnych miałby w 93 roku (na rok 92), a fakt, że konsulatu wówczas nie zdobył, wynikał z dużej konkurencji o najwyższy urząd w państwie wśród patrycjuszy ${ }^{30}$. Podstawowym mankamentem hipotezy Sumnera jest brak oparcia w materiale źródłowym, nie znalazła więc ona większego poparcia wśród uczonych.

Większość badaczy jest jednak zdania, że nie ma sensu podważać przekazu Plutarcha i uważa, że Sulla rzeczywiście zrezygnował ze starań o edylat, od razu przystępując do wyborów pretorskich. Najbardziej prawdopodobną przyczyną tej rezygnacji był pośpiech. Przypomnijmy, że w 107 roku Sulla sprawował kwesturę (być może suo anno) ${ }^{31}$ i teraz suo anno chciał piastować preturę. Wiadomo, że Rzymianie cenili osiąganie urzędów w najwcześniejszym momencie, w którym umożliwiało to prawo $^{32}$. Jako że wiek wymagany do ubiegania się o urząd pretora wynosił 39 lat $^{33}$, Sulla - urodzony, jak wspomniałem, niemal na pewno w 138 roku - najwcześniej mógł wystartować w wyborach w 99 roku na rok 98. Wydaje się, że właśnie

29 App., BC 1.40.180. Por. Cic., Font. 43.

30 W 92 roku konsulem został G. Klaudiusz Pulcher, w 91 Sex. Juliusz Cezar, a w 90 L. Juliusz Cezar. Zob. G.V. Sumner, Sulla's Career..., s. 396.

31 Tak uważa Badian (Sulla's Cilician Command..., s. 159, ale por. s. 174, przyp. 13).

32 Por. Cic., In Pis. 2; De off. 2.59; Brut. 321, 323.

33 A. Afzelius, Lex annalis, „Classica et Mediaevalia” 1946, 8, s. 278; A.E. Astin, The Lex Annalis before Sulla, Part II, „Latomus” 1958, 17, s. 64; T. Corey Brennan, The Praetorship in The Roman Republic, Oxford 2000, s. 392. 
taką chronologię poświadcza Plutarch, który sugeruje, że Sulla przystąpił do wyborów pretorskich od razu po przybyciu do Rzymu z wojny z Cymbrami i Teutonami ${ }^{34}$.

Powróćmy jednak do przyczyn porażki Sulli w pierwszych wyborach pretorskich. Prawdopodobnie nie chodziło jedynie o odwet zawiedzionych wyborców oczekujących, że Sulla - edyl wyprawi igrzyska. Wiadomo bowiem, że zwycięstwo w wyborach o wyższe urzędy wiązało się ze zdobyciem wystarczającego poparcia wśród elity, która następnie wpływała na swoich klientów w sprawie głosowania na odpowiedniego kandydata. Wydaje się, że Sulla, który co najmniej od 107 roku był związany z Mariuszem ${ }^{35}$, mógł liczyć na jego wyborców. Tymczasem po szóstym konsulacie Mariusza, gdy po wojnach z Germanami wreszcie nastał w państwie pokój, pozycja tego wodza w Republice wyraźnie się pogorszyła. Widać to właśnie na przykładzie wyborów na rok 98. Konsulat obsadzili wówczas Kwintus Cecyliusz Metellus Nepos i związany z Metellusami Tytus Dydiusz ${ }^{36}$. Do factio Metellusów - a zatem przeciwników sześciokrotnego konsula - zbliżeni byli również pretorzy tego roku, Lucjusz Licyniusz Krassus i Kwintus Mucjusz Scewola ${ }^{37}$. Tak duża kontrola wyborów przez opozycję antymariańską mogła mieć wpływ na porażkę wyborczą Sulli - człowieka kojarzonego dotąd z Mariuszem.

W następnym roku po fiasku wyborczym (czyli w 98) Sulla ponownie wystartował w wyborach pretorskich. Doskonale się do nich przygotował i tym razem wygrał ${ }^{38}$. Nie bez znaczenia wydaje się także fakt, że zmieniła się konfiguracja polityczna w państwie - w wyborach na 97 rok zwycięstwo odnieśli bowiem zwolennicy Mariusza. Cenzurę objęli wówczas kojarzeni z tym wodzem Lucjusz Waleriusz Flakkus i Marek Antoniusz, a Mariusz

${ }^{34}$ Plut., Sulla 5.1: „Otrzymawszy zwolnienie z armii, natychmiast zaczął się ubiegać o stanowisko w administracji państwowej i zgłosił swą kandydaturę na pretora” (tłum. M. Brożek).

35 Sall., Iug. 95-96.

36 E. Badian, Caepio and Norbanus, „Historia” 1957, 6, s. 338.

37 Ibidem, s. 328.

38 Plut., Sulla 5.2. 
prawdopodobnie miał wpływ na ich wybór ${ }^{39}$. Jednym z konsulów został z kolei Publiusz Licyniusz Krassus, również w tym czasie związany z sześciokrotnym konsulem ${ }^{40}$. Możliwe zatem, że jego zwolennicy wspierali także kandydaturę Sulli.

Sulla, mając w pamięci ubiegłoroczną porażkę, przeprowadził skuteczną kampanię wyborczą. Musiał zdawać sobie sprawę z tego, że jedną z przyczyn zeszłorocznego niepowodzenia było pominięcie na wcześniejszym etapie kariery edylatu, a w zasadzie przewagi, jaką dawało sprawowanie tego urzędu. Udanie odbyty edylat - czyli zapewnienie ludowi rzymskiemu rozrywki i zdobycie dzięki temu popularności - wzmacniało wszak szansę w wyborach na wyższe urzędy państwowe i elita rzymska była tego w pełni świadoma ${ }^{41}$. Sulla miał dwa wyjścia - albo zrezygnować z kandydowania na pretora i piastować edylat (tę ewentualność, z powodu braku potwierdzenia w źródłach, odrzuciłem wyżej), albo spowodować, aby lud wybrał go na pretora, na przykład obiecując, po ewentualnej elekcji, organizację wyczekiwanych przez mieszkańców stolicy igrzysk.

Sulla mógł oczywiście zorganizować igrzyska podczas pretury, pod warunkiem jednak, że zostałby pretorem miejskim. I rzeczywiście - Plutarch podaje, że przyszły dyktator zgłosił swą kandydaturę na pretora miejskiego (praetor urbanus), skądinąd wiadomo także, że po zwycięstwie w wyborach taki urząd właśnie pełnił ${ }^{42}$. Problem polega na tym, że Rzymianie nie startowali $\mathrm{w}$ wyborach na konkretną preturę i podziału na pretorów dokonywano już po ogłoszeniu wyników wyborów poprzez losowanie między wybranymi kandydatami. Spośród sześciu wybieranych co rok pretorów tylko jeden mógł piastować urząd pretora miejskiego (uważany za najbardziej zaszczytny), a to powodowało, że szansa na wylosowanie akurat takiego przydziału, pozwalającego Sulli na wystawienie igrzysk, była niewielka. Ryan wymienia jednak co najmniej trzy sposoby, dzięki którym Sulla mógł próbować zapewnić sobie preturę miejską jeszcze przed wyborami:

${ }^{39}$ E. Badian, Caepio..., s. 333. T.F. Carney, A Biography of C. Marius, Chicago 1970, s. 47.

${ }^{40}$ E. Badian, Caepio..., s. 332.

41 Por. Cic., Off. 2.58. A.E. Astin, The Lex Annalis before Sulla, Part I, „Latomus” 1957, 16, s. 596.

42 Vir. ill. 75.3. 
po pierwsze mógł przekonywać lud, że ma dobre stosunki z konsulami, którzy kierowali sortitio provinciarum i dzięki tym znajomościom dokonają oni korzystnego dla niego przydziału ${ }^{43}$. Minusem takiego argumentu jest fakt, że - jak już wspominałem - obydwaj konsulowie 98 roku byli Sulli nieprzychylni i trudno byłoby mu się z nimi ułożyć. Drugą możliwością było obiecanie elektoratowi, że po wyborach Sulla - w przypadku gdyby los go zawiódł i nie wylosowałby pretury miejskiej - i tak dostanie na nią nominację dzięki comparatio, czyli porozumieniu z pozostałymi kandydatami. Wiadomo, że gdyby Sulla odpowiednio nagłośnił tę sprawę, a ktoś inny zostałby pretorem miejskim i mimo wszystko odmówiłby zamiany, spotkałby się z niechęcią ludu, któremu wszak Sulla w kampanii wyborczej obiecał igrzyska ${ }^{44}$. Minusem tego argumentu jest z kolei brak informacji w źródłach o większości innych kandydatów (oprócz Sulli z nazwiska znany jest tylko jeden pretor 97 roku, Lucjusz Domicjusz Ahenobarbus, który sprawował urząd na Sycylii ${ }^{45}$ ), a zwłaszcza o ich obietnicach wyborczych kierowanych do ludu. W związku z tym stawianie hipotezy o comparatio wydaje się ryzykowne. Wreszcie trzecia ewentualność: Sulla mógł skłonić senatorów, aby jeszcze przed wyborami (albo przed losowaniem) uchwałą zapewnili mu preturę miejską extra sortem. Takie sytuacje zdarzały się jednak niezmiernie rzadko $^{46}$. Istnieje jeszcze czwarta możliwość, w dodatku wymieniona przez Plutarcha, czyli zastosowanie przez Sullę przekupstwa ${ }^{47}$. Reams spekuluje, że Sulla mógł posłużyć się przekupstwem, np. na concilium plebis - wystarczyło, że przekupiony trybun ludowy zgłosiłby wniosek o przyznanie mu pretury miejskiej i przegłosowano by w tej sprawie odpowiednią uchwałę (plebiscitum) ${ }^{48}$. Wiadomo, że już w trakcie sprawowania pretury Cezar Strabon zarzucał Sulli przekupstwo ${ }^{49}$. Oskarżenie niekoniecznie musiało dotyczyć wyborów pretorskich, ale sytuacji już po wyborach, gdy Sulla za wszelką cenę chciał uzyskać nominację na pretora miejskiego i być może

\footnotetext{
${ }^{43}$ F.X. Ryan, The Second Praetorian Campaign..., s. 401.

${ }^{44}$ Ibidem.

45 Cic., Verr. 2.5.7. T.R.S. Broughton, The Magistrates..., vol. 2, s. 7.

46 F.X. Ryan, The Second Praetorian Campaign..., s. 402.

47 Por. Plut., Sulla 5.2.

${ }^{48}$ L.E. Reams, The First Fifty Years of Sulla..., s. 96.

49 Plut., Sulla 5.2.
} 
wówczas dopuścił się nadużycia. Jakkolwiek było, faktem jest, że po wygranych wyborach Sulla dołożył wszelkich starań, aby dostać nominację na pretora miejskiego. Przekaz Plutarcha jest więc wiarygodny, a jedyny błąd biografa polega na tym, że przypisuje Sulli kandydowanie na pretora miejskiego w pierwszej, przegranej kampanii, gdy tymczasem chodziło ewidentnie o kampanię drugą, zwycięską.

Sulla wygrał zatem wybory pretorskie na 97 rok i rzeczywiście pełnił funkcję pretora miejskiego ${ }^{50}$. Wiadomo, że spełnił obietnicę wyborczą i wyprawił wspaniałe ludi Apollinares ${ }^{51}$. Bez wątpienia nawiązał do pierwszych tego typu igrzysk, jakie w 212 roku zorganizowal jego przodek, pretor Publiusz Korneliusz Sulla ${ }^{52}$. Dzięki przyjaźni z królem Mauretanii Bokchusem Sulli udało się sprowadzić do Rzymu lwy i numidyjskich myśliwych, którzy - ku radości gawiedzi - polowali na nie na arenie. Keaveney słusznie zauważa także, że igrzyska wyprawione na cześć Apolla to pierwszy w źródłach ślad szczególnej czci Sulli dla tego boga, co z jednej strony wpisuje się w tradycję rodu, z którego się wywodził, z drugiej stanowi zaś wstęp do eksponowanej w źródłach religijności Sulli ${ }^{53}$.

Drugie wydarzenie z okresu pretury Sulli dotyczy wspomnianej już próby oskarżenia go przez Cezara Strabona o przekupstwo w trakcie wyborów ${ }^{54}$. Wiadomo, że oskarżyciel był wrogiem Mariusza i członkiem factio Metellusów ${ }^{55}$. Zarzuty Strabona dobrze wpisują się zatem w ówczesne zaangażowanie Sulli po stronie Mariusza. Sprawa rzekomego przekupstwa w źródłach potraktowana jest lakonicznie, nie wydaje się również, aby stała się podstawą do jakiegoś procesu. Skutkiem spięcia Sulli z Cezarem Strabo-

50 Vir. ill. 75.3. J. Fündling, Sulla..., s. 44.

51 Plin., NH 8.53; Sen., Brev. Vit. 13.6.

52 T.R.S. Broughton, The Magistrates..., vol. 1, s. 268. H.H. Scullard, Festivals and Ceremonies of the Roman Republic, London 1981, s. 159-160; H. Behr, Die Selbstdarstellung Sullas. Ein aristokratischer Politiker zwischen persönlichem Führungsanspruch und Standessolidarität, Frankfurt am Main 1993, s. 25; L. Telford, Sulla..., s. 72.

53 A. Keaveney, Sulla..., s. 41.

${ }^{54}$ Plut., Sulla 5.2; L. Telford, Sulla..., s. 71.

55 E. Badian, Caepio..., s. 332; E.S. Gruen, The Lex Varia, „The Journal of Roman Studies" 1965, 55, s. 72. 
nem była natomiast wrogość między nimi, która nie wygasła nawet wówczas, gdy Sulla był już kojarzony z factio Metellusów ${ }^{56}$.

Po złożeniu pretury Sulla został wysłany niemal na pewno pro consule do Cylicji (być może jako namiestnik Azji, jako że nie jest pewne, czy prowincja Cylicja już istniała ${ }^{57}$ ). Wybór miejsca namiestnictwa był chyba nieprzypadkowy - prawdopodobnie na tamtym terenie służbę pełnił niegdyś ojciec Sulli ${ }^{58}$, dzięki czemu mógł tam wówczas pozyskać klientów. Niewykluczone także, że Sulla - powiązany wszak wciąż z Mariuszem - wyjeżdżał na Wschód, aby dbać tam o interesy tego wodza ${ }^{59}$. Na podstawie miejsca namiestnictwa można również domyślać się zadań, jakie powierzono Sulli - prawdopodobnie miał między innymi zwalczać szerzące się w tamtym rejonie piractwo ${ }^{60}$. Już po wyjeździe na Wschód Sulla otrzymał dodatkową misję - miał przywrócić na tron Kapadocji Ariobarzanesa odsuniętego od sprawowania władzy przez króla Pontu Mitrydatesa VI Eupatora ${ }^{61}$. Zapewne dodatkowe zadania, które Sulla otrzymał od senatu, wydłużyły jego namiestnictwo w Cylicji co najmniej o dwa lata. Wiadomo, że akcja osadzenia Ariobarzanesa na tronie Kapadocji powiodła się, Sulla - po uprzednim dokonaniu zaciągu w prowincji - pokonał w Kapadocji siły przeciwne Ariobarzanesowi, a następnie - być może w 94 roku - udał się w kierunku Eufratu, gdzie doszło do sławnego spotkania z posłem partyjskim Orobazusem ${ }^{62}$. Był to pierwszy odnotowany w źródłach kontakt imperium rzymskiego z Partami.

56 A. Keaveney, Sulla, Sulpicius and Caesar Strabo, „Latomus” 38, 1979, s. 455; idem, Sulla..., s. 58-59; T. Ładoń, Seditio Sulpiciana (88 rok przed Chrystusem), [w:] Przemoc $w$ świecie starożytnym. Źródta - struktura - interpretacje, red. D. Słapek, I. Łuć, Lublin 2017, s. 212-215.

57 Zob. A.N. Sherwin-White, Rome, Pamphylia and Cilicia, 133-70 B.C., "The Journal of Roman Studies” 1976, 66, s. 1-14. Por. jednak W. Letzner, Lucius Cornelius Sulla..., s. 93, przyp. 44.

58 Por. App., Mith. 54.216.

59 L.E. Reams, The First Fifty Years of Sulla..., s. 97.

${ }^{60}$ A. Keaveney, Sulla..., s. 41. Por. jednak P. de Souza, Piraci w świecie grecko-rzymskim, Zakrzewo 2008, s. 143-144.

${ }^{61}$ Plut., Sulla 5.3; Liv., Per. 70.

${ }^{62}$ Plut., Sulla 5.4-5; Liv., Per. 70; Fest., Brev. 15; Ampelius 31; Vell. Pat. 2.24.3. A. Keaveney, Roman Treaties with Parthia circa 95 - circa 64 B.C., „The American Journal 
Namiestnictwo Sulli na Wschodzie zakończyło się pełnym sukcesem. Do Rzymu prokonsul powrócił najwcześniej w 93, a prawdopodobnie dopiero w 92 roku $^{63}$. Jego pozycja na rzymskiej scenie politycznej niewątpliwie wzrosła, wydaje się więc, że naturalne byłyby jak najszybsze starania o konsulat. Tymczasem wiadomo, że Sulla na urząd ten kandydował dopiero w 89 roku i pełnił go w roku 88. Na tę kilkuletnią zwłokę złożyło się kilka czynników.

Pierwszy to rozluźnienie stosunków przyszłego dyktatora z Mariuszem. Kiedy dokładnie do tego doszło, nie sposób stwierdzić, gdyż nie zachowały się na ten temat dane źródłowe. Wiadomo tylko, że w momencie wyjazdu do Azji Sulla prawdopodobnie wciąż uważany był za człowieka związanego z sześciokrotnym konsulem, po powrocie zaś sytuacja najwyraźniej się zmieniła i relacje pomiędzy dwoma dotychczasowymi sprzymierzeńcami uległy ochłodzeniu.

Jedną z przesłanek uprawniającą do wydania takiego sądu jest oskarżenie, jakie przeciwko Sulli wniósł niejaki Censorinus, identyfikowany z Gajuszem Marcjuszem Censorinusem, późniejszym zwolennikiem Mariusza i Cynny, straconym na rozkaz Sulli po bitwie przy Bramie Kollińskiej w 82 roku $^{64}$. Oskarżenie najpewniej dotyczyło nadużyć, jakich Sulla miał dopuścić się podczas namiestnictwa na Wschodzie. Badacze podejrzewają, że za oskarżeniem mógł stać Mariusz, a Censorinus był zaledwie wykonawcą jego woli ${ }^{65}$. Nie ma jednak twardych dowodów potwierdzających taki wniosek. Współpraca Censorinusa z obozem cynno-mariańskim jest poświadczona dopiero w okresie pierwszej wojny domowej, kiedy konfiguracja polityczna w państwie uległa całkowitej zmianie. Dodatkowo nie

of Philology" 1981, 102, s. 195-198; P. Arnaud, Sylla, Tigrane et les Parthes. Un nouveau document pour la datation de la propréture de Sylla: Sidoine Apollinaire, Paneg. Aviti, 79-82, „Revue des Études“ 1991, 93, s. 55-64.

${ }^{63}$ T. Corey Brennan, Sulla's Career..., s. 155.

${ }^{64}$ Plut., Sulla 5.6; Firm. Mat. 1.7.28. M.A. Alexander, Trials in the Late Roman Republic, 149 BC to 50 BC, Toronto-Buffalo-London 1990, s. 92; L.E. Reams, Censorinus, Sulla, and Marius, „Rheinisches Museum für Philologie”1993, 136, s. 281-288. O G. Marcjuszu Censorinusie zob. F. Münzer, C. Marcius Censorinus (43), [w:] RE, Bd. 14, Stuttgart 1930, szp. 1550-1551.

${ }^{65}$ E. Badian, Lucius Sullla. The Deadly Reformer, Sydney 1970, s. 10. 
wiadomo, czy Censorinus działał w ogóle na czyjeś polecenie, czy była to po prostu niezwiązana z ówczesną polityką akcja młodego arystokraty szukającego sławy i szczęścia w sądzie. Nieudolność działań młodego Censorinusa (Cyceron nie miał o nim najlepszego zdania, skoro pisał, że „wydawał się trochę powolny i nie lubił forum”"66), który koniec końców odstąpił od oskarżenia i nie pojawił się $\mathrm{w}$ sądzie ${ }^{67}$, przemawia raczej za tą drugą ewentualnością ${ }^{68}$. Nie wydaje się więc możliwe, aby snute przez uczonych podejrzenia, jakoby oskarżenie Censorinusa miało bezpośredni wpływ na odłożenie przez Sullę marzeń o konsulacie o kilka lat, miało odzwierciedlenie w faktach.

Inna przesłanka uprawniająca do podejrzeń, że stosunki między Mariuszem i Sullą uległy pod koniec lat dziewięćdziesiątych ochłodzeniu, opiera się na zbliżeniu się przyszłego dyktatora do obozu Metellusów. Problemem znów jest chronologia. Co prawda, o ile nie ma wątpliwości, że taki sojusz rzeczywiście nastąpił i Sulla związał się z factio Metellusów, to formalne zawarcie przymierza można datować dopiero na 89 rok, wtedy bowiem najpewniej doszło do małżeństwa Sulli z Cecylią Metellą ${ }^{69}$. Wydaje się jednak, że rozmowy przedstawicieli factio Metellusów z niedawnym prokonsulem zaczęły się znacznie wcześniej, a u ich genezy leżało wzmocnienie jego pozycji w państwie po preturze i udanym namiestnictwie w Cylicji.

O ile zerwanie przyjacielskich relacji Sulli z Mariuszem pozostaje poza dyskusją, to przyczyny rozluźnienia ich wzajemnych relacji - z braku informacji zawartych w przekazach antycznych - muszą pozostać w sferze spekulacji. Możliwe, że do konfliktu doszło w czasie pobytu Sulli na

${ }^{66}$ Cic., Brut. 237 (tłum. M. Nowak).

${ }^{67}$ Badacze podają różne powody odstąpienia Censorinusa od oskarżenia, w tym możliwość przekupienia go przez Sullę (J. Carcopino, Sylla ou la monarchie manquée, Paris 1931, s. 25) czy beznadziejność sprawy spowodowanej brakiem dowodów (E. Gruen, Roman Politics and the Criminal Courts, 149-78 B.C., Cambridge 1968, s. 198).

${ }^{68}$ L.E. Reams, Censorinus..., s. 287. Por. przypadek Cezara, który zdobywał doświadczenie sądowe, oskarżając G. Antoniusza w 76 roku. T. Ładoń, Mark Antony's Forefathers. Comments on the Role of the gens Antonia in the Final Period of the Roman Republic, [w:] Marcus Antonius. History and Tradition, red. D. Słapek, I. Łuć, Lublin 2016, s. 141.

69 Plut., Sulla 6.10; F. Münzer, Caecilia Metella, [w:] RE, Bd. 3, Stuttgart 1897, szp. 1234-1235. 
Wschodzie. Powierzenie Sulli przez senat misji przywrócenia na tron Ariobarzanesa może świadczyć o zaufaniu, jakim cieszył się wśród arystokracji senatorskiej i nie można wykluczyć, że już wówczas w senacie postrzegano go jako przeciwwagę dla Mariusza.

Choć problemem jest dokładne datowanie początku wrogości między Mariuszem a Sullą, to bez większych wątpliwości można stwierdzić, kiedy ta niechęć na pewno już istniała. Chodzi tutaj o sławną sprawę ustawienia na Kapitolu posągów bogiń zwycięstwa z trofeami wojennymi upamiętniającymi sukces Rzymian w wojnie jugurtyńskiej. Znalazła tam swoje odwzorowanie również scena, w której Bokchus przekazuje Jugurtę w ręce Sulli, jemu tym samym oddając chwałę za zwycięstwo nad władcą numidyjskim. Wydarzenie to - jak twierdzi Plutarch - wywołało u Mariusza tak wielką wściekłość i obrazę, że doprowadziło niemal do wybuchu rozruchów w Rzymie ${ }^{70}$.

Oczywiście inicjatywa ustawienia posagów mogła należeć do Bokchusa - przypominając o zasługach, jakie oddał niegdyś Rzymowi, chciał on uzyskać jakieś własne, partykularne korzyści, o których można tylko spekulować ${ }^{71}$. Mało prawdopodobne, aby to Sulla był inicjatorem tego pomysłu, natomiast zapewne pomógł w jego realizacji i nie uczynił tego bezinteresownie. Dodajmy, że ustawienie posagów musiało być zaakceptowane wcześniej przez senat, co może wskazywać, że akcja Bokchusa i Sulli cieszyła się poparciem większości senatorów. Być może Sulla chciał tę sytuację wykorzystać i wspólne działanie z Bokchusem stanowiło początek kampanii wyborczej w walce o konsulat. Propagandowy wydźwięk przekazu był wszak oczywisty, a celem nie mogło być jedynie rozwścieczenie Mariusza. Podobny oddźwięk musiał wywołać pierścień, na którym wygrawerowano scenę pojmania Jugurty przez Sullę, datowany na mniej więcej ten okres ${ }^{72}$. Tak jawne wystąpienie przeciwko sześciokrotnemu konsulowi, w dodatku przy wsparciu senatu, powodowało, że Sulla stawał na czele koalicji złożo-

70 Plut., Sulla 6.1-2; Mar. 32.2.

71 P.F. Cagniart, L. Cornelius Sulla..., s. 294 n.

72 Plut., Mar. 10.5, Sulla 3.4, Mor. 806d; Val. Max. 8.14.4; Plin., NH37.8. Możliwe, że scena uwieczniona na denarze wybitym przez Faustusa Sullę w 56 roku nawiązuje do sceny z pierścienia. Por. M.H. Crawford, Roman Republican Coinage, vol. 1, Cambridge 1974, s. 449-451. 
nej z przeciwników Mariusza. Dawało mu to kapitalną pozycję do zdobycia najważniejszego urzędu w państwie.

Nie wszystko jednak układało się po myśli Sulli. W walce o konsulat na pewno chciał wykorzystać swoje niedawne sukcesy odniesione w trakcie namiestnictwa na Wschodzie. Tymczasem po jego wyjeździe sytuacja Ariobarzanesa w Kapadocji uległa pogorszeniu, co rzucało złe światło na dokonania prokonsula ${ }^{73}$. Sytuację w państwie skomplikował także wybuch wojny ze sprzymierzeńcami. Dodatkowo do walki o konsulat rok po roku stawali przedstawiciele najznamienitszych rodów patrycjuszowskich: G. Waleriusz Flakkus, G. Klaudiusz Pulcher, Sex. Juliusz Cezar i L. Juliusz Cezar (odpowiednio konsulowie lat 93, 92, 91 i 90) ${ }^{74}$, którzy mogli pochwalić się wieloma przodkami - konsulami, podczas gdy świetność rodu Sulli od blisko dwóch stuleci przygasła. Stawiało go to na przegranej pozycji, nic więc dziwnego, że w zaistniałych okolicznościach postanowił (czy też został zmuszony) odłożyć marzenia o konsulacie na dalszy czas.

Wellejusz Paterkulus, charakteryzując Sullę, pisze, że przez długi czas postępował on, „jakby w ogóle nie zamierzał starać się o konsulat” i dopiero gdy „po preturze zabłysnął w wojnie italskiej, tak jak poprzednio, pod rozkazami Mariusza w Galii (...) w miarę powodzenia nabrał otuchy"75. Skłoniło to Cagniarta do postawienia wniosku, że Sulla nie był predestynowany do bycia konsulem od urodzenia i że jego konsulat był wyłącznie wynikiem zbiegu okoliczności, których nie mógł przewidzieć, czyli że zawdzięczał go sukcesom odniesionym w trakcie wojny ze sprzymierzeńcami ${ }^{76}$. Taka konstatacja nie wydaje się do końca słuszna. To prawda, że Sulla nie pochodził z rodu patrycjuszowskiego wiodącego prym na ówczesnej scenie politycznej, niemniej i jego przodkowie od kilkuset lat byli obecni w rzymskiej polityce. Na starcie kariery dysponował większymi szansami niż każdy homo novus. Oczywiście członkowie bardziej znamienitych rodów mieli łatwiejszą drogę do najwyższych godności, ale Sulla - jak wielu obecnych w polityce

${ }^{73}$ A.N. Sherwin-White, Ariobarzanes..., s. 182-183; T. Corey Brennan, Sulla's Career..., s. 156.

74 T.R.S. Broughton, The Magistrates..., vol. 2, s. 14, 17, 20, 25.

75 Vell. 2.17.2 (tłum. E. Zwolski).

76 P.F. Cagniart, L. Cornelius Sulla..., s. 298-303. 
arystokratów - kierował się ambicją i chciał osiągnąć jak najwięcej. I gdy dzięki osobistym zdolnościom i uporowi wreszcie osiągnął preturę - bo to wszak ten sukces Wellejusz Paterkulus wskazuje jako przełomowy moment wczesnej kariery Sulli - uwierzył, że jako pierwszy Korneliusz Sulla w historii może dojść do najwyższej godności w państwie i temu celowi podporządkował swoje kolejne działania. 